\title{
Axis instrumentation: surgical results
}

\author{
Instrumentação do áxis: resultados cirúrgicos \\ Andrei F. Joaquim?', Enrico Ghizoni', Diogo V. Anderle², Evandro de Oliveira ${ }^{3}$, Helder Tedeschi
}

\begin{abstract}
Objective: Evaluate the surgical results of axis screw instrumentation. Methods: Retrospective evaluation of the clinical and radiological data of patients submitted to axis fixation using screws. Results: Seventeen patients were surgically treated. The mean age was 41.8 years (range: 12-73). Spinal cord trauma was the most common cause of instability (8 patients - 47\%). Bilateral axis fixation was performed in all cases, except one, with laminar screw (total of 33 axis screws). Seven patients (41.1\%) underwent bilateral pars screws; laminar screws were used in six cases and pedicular screws were used in two. In two cases, we performed a hybrid construction (laminar + pars and pedicle + pars). There was no neurological worsening or death, nor complications directly related to use axis screws. Conclusion: Axis instrumentation was effective and safe, regardless of the technique used for stabilization. Based on our learnt experience, we proposed an algorithm to choose the best technique for axis screw fixation.
\end{abstract}

Key words: axis, instrumentation, pedicle, pars, laminar, bone screws.

\section{RESUMO}

Objetivo: Avaliar os resultados cirúrgicos da instrumentação com parafusos do áxis. Métodos: Avaliação retrospectiva de dados clínicos e radiológicos de pacientes submetidos à instrumentação com parafusos do áxis. Resultados: Dezessete pacientes foram tratados cirurgicamente. A média de idade foi de 41,8 anos (faixa: 12-73 anos). Trauma na coluna foi a causa mais comum de instabilidade (8 casos 47\%). Fixação bilateral do áxis foi realizada em todos os casos, exceto em um, com parafuso de lâmina (total de 33 parafusos). Em sete pacientes (41,1\%), foram usados parafusos de pars; em seis, parafusos de lâmina; e em dois, de pedículos. Em dois casos, foi utilizada uma combinação de técnicas (pars + lâmina e pars + pedículo). Não houve piora neurológica nem complicações diretas em decorrência do uso dos parafusos. Conclusão: A instrumentação do áxis foi eficaz e segura independentemente da técnica escolhida para estabilização. Com base em nossa experiência, foi proposto um algoritmo para auxílio na escolha da melhor técnica a ser empregada.

Palavras-Chave: áxis, instrumentação, pedículo, pars, lâmina, parafusos ósseos.

Many pathological conditions, such as trauma, degenerative, inflammatory and neoplastic diseases, or even congenital malformations, can lead to segmental instability in the upper cervical spine, requiring fixation procedures to maintain or restore stability ${ }^{1-5}$. Due to the unique anatomy of the axis, the second cervical vertebra, achieving segmental stability surgically can be challenging at times. Although they are less complex procedures, wiring techniques have a high rate of nonunion ${ }^{6-8}$, leading to an incomplete immobilization ${ }^{9,10}$, sometimes requiring the use of an external orthosis postoperatively. Trying to improve the quality of the stabilization and the arthrodesis rate, a large number of axis screws fixation techniques were described, biomechanically more efficient and stronger than wiring techniques ${ }^{11,12}$.

The use of pedicular screws in the axis was first described by Goel A. and Laheri V. in 1994. This is probably the technique that offers the strongest fixation ${ }^{13}$. However, in up to $20 \%$ of the cases, it can be inadvisable due pedicles size limitations or a vertebral artery located medially ${ }^{14,15}$.

Another important technique is the use of pars interarticularis screws, also known as isthmus screws. This technique is similar to that described for transarticular C1-2 screws, but it's based on smaller length screws that do not transgress the

\footnotetext{
${ }^{1}$ Assistant Neurosurgeon, Universidade Estadual de Campinas (UNICAMP), Campinas SP, Brazil;

${ }^{2}$ Neurosurgeon, Santa Casa de Amparo, Amparo SP, Brazil;

${ }^{3}$ Assistant Professor, Neurosurgery Division, UNICAMP, Campinas SP, Brazil.

Correspondence: Andrei F. Joaquim; Rua Antônio Lapa 280 / 5ªndar / sala 506 / Edifício América Cambuí; $13025-240$ Campinas SP - Brasil;

E-mail:andjoaquim@yahoo.com

Conflict of interest: There is no conflict of interest to declare.

Received 28 January 2012; Received in final form 22 June 2012; Accepted 29 June 2012
} 
C1-2 facet joint ${ }^{16}$. The risk of vertebral artery injury, although rare, exists and can be catastrophic.

The third axis screw fixation technique described in the spinal literature is the insertion of laminar screws, that can be used in patients who did not require a laminectomy and have a prohibitive pedicle or pars anatomy ${ }^{16,17}$.

We present our clinical results in a series of patients that underwent axis screw instrumentation, discussing surgical nuances of the technique used. Based on our experience, we proposed an algorithm for helping surgeons to choose the best technique for axis screw instrumentation.

\section{METHODS}

A retrospective evaluation of a personal series (AFJ) of patients that underwent axis stabilization with screws from January 2009 to December 2011 was performed. Inclusion criteria: patients that underwent surgery that included C2 fixation with screws. Exclusion criteria: patients that did not consent with the participation in this study during the follow-up. All the patients consent with the participation in this study.

Clinical data assessed includes: age, sex, follow-up, surgical indication, surgical complications and neurological status. Radiological data was used to assess the technique of fixation used, screw misplaced and late radiological complications.

Considering the surgical technique used, it is important to mention that there are different trajectories for the screw insertion. In case of pedicle screws, the entry point is just lateral to the superior margin of the lamina, towards the top of the pars ${ }^{16}$. The trajectory for drilling the $\mathrm{C} 2$ pedicle is about 20 degrees up and 15-25 degrees medially ${ }^{16}$. The final direction is also very dependent on any rotational variations noted on preoperative CT scans. For C2 pars screws, the starting point is selected in the medial half of the inferior facet of $\mathrm{C} 2(2 \mathrm{~mm}$ up and $2 \mathrm{~mm}$ in), in the pars' direction, guided by lateral fluoroscopy image, generally in a cranial and slightly medial direction, similar to the transarticular C1-2 screw technique ${ }^{16}$.

\section{RESULTS}

Seventeen patients enrolled in this study. Mean age was 41.8 years-old (range from 12 to 73 years-old). Ten patients were men (58.8\%) and seven (41.1\%) were women. The mean followup was 9.56 months (range 2-24; median 7.5 months). One patient lost follow-up immediately after hospital discharge.

Eight patients (47\%) required stabilization to treat instability secondary to spinal trauma, followed by three cases of congenital craniocervical malformation (17.6\%), two cases of tumor (one spinal metastasis and one giant cell tumor) and two cases of cervical myelopathy involving the axis (11.7\%). We also have one case of rheumatoid arthritis leading to C1-2 instability and a postlaminectomy kyphosis after late resection of an extradural giant schwannoma tumor (5.8\%).

Nine patients $(52.9 \%)$ required concomitant $\mathrm{C} 1$ fusion using lateral mass screws, five cases (29.4\%) underwent an occipitocervical fusion, and three cases (17.6\%) had subaxial cervical decompression and fusion with lateral mass screws.

The summary of the clinical data of the seventeen cases is presented in Table 1 and case examples are shown in Figs 1 to 5.

In all but one cases, a bilateral $\mathrm{C} 2$ instrumentation was performed, with a total of 33 screws used. In seven cases (41.1\%), we used bilateral pars screws; laminar screws were used in five cases $(29.4 \%)$, and pedicular screws were used in two $(11.7 \%)$ (Table 2). In two cases, we performed a hybrid construction with laminar and pars screws, and the other with pedicle and pars screws. In the patient with $\mathrm{C} 1-2$ instability secondary to rheumatoid arthritis, because of total destruction of the right $\mathrm{C} 1$ lateral mass, we performed a unilateral left side C1 lateral mass - C2 laminar screw fixation.

All the patients that were neurologically intact before surgery remained intact after the procedure (ten cases). The seven patients who had some neurological deficit before surgery had significant improvement after the procedure in muscular strength or gait ability (patients 7, 8, 9, 11, 14, 15 and 16).

Regarding C1 instrumentation performed in nine cases with lateral mass screws, in three cases there were some degree of $\mathrm{C} 1$ subluxation over $\mathrm{C} 2$, reduced after rod insertion. In five cases, the $\mathrm{C} 2$ ganglion was resected to improve the visualization of the $\mathrm{C} 1$ lateral mass. The patients in this group had transitory paresthesias and hypoesthesia in the nerve territory, but they did not need medicamentous therapy. However, two of the four patients in which the $\mathrm{C} 2$ nerve roots were preserved developed postoperative neuropathic occipital pain that required clinical treatment.

In all patients we used autologous iliac crest as bone graft. In one case, we had a superficial infection in the site where the graft was harvested.

There was no neurological worsening or death in this series, nor complications related directly to the use of axis screws. The most common complication was superficial wound infection in three cases (17.6\%), all of them in occipital-cervical fusions.

\section{DISCUSSION}

Historically, the anatomic terminology is confusing about the definition of the differences between the axis pedicle and its pars articularis, with both terms being used interchangeably in most papers. Ebraheim et al. defined that the pedicle is the portion located beneath the superior facet joint and anteromedial to the transverse foramen of the axis. The pars interarticularis or isthmus is the narrow osseous band located between the superior and the inferior facet joints ${ }^{18}$. 
Table 1. Clinical characteristics of the 11 patients with axis instrumentation.

\begin{tabular}{|c|c|c|c|c|c|c|c|}
\hline $\mathrm{n}$ & Sex & Age & Group & Ethiology & Surgery & Infecction & Follow-up (months) \\
\hline 1 & M & 16 & Trauma & Odontoid type II fracture & $\begin{array}{c}\text { C1 lateral mass screws } \\
\text { and C2 pedicular } \\
\text { screws }\end{array}$ & No & 18 \\
\hline 2 & M & 46 & Trauma & Odontoid type II fracture & $\begin{array}{l}\mathrm{C} 1 \text { lateral mass screws } \\
\text { and } \mathrm{C} 2 \text { pars screws }\end{array}$ & No & 7 \\
\hline 3 & $\mathrm{~F}$ & 34 & Trauma & Odontoid type II fracture & $\begin{array}{l}\text { C1 lateral mass screws, } \\
\text { C2 pars screw and C3 } \\
\text { lateral mass screw }\end{array}$ & $\begin{array}{l}\text { Superficial } \\
\text { wound infection } \\
\text { at the iliac crest }\end{array}$ & 4 \\
\hline 4 & M & 48 & Trauma & Transverse ligament injury & $\begin{array}{l}\text { C1 lateral mass screws } \\
\text { and C2 laminar and } \\
\text { pars screws }\end{array}$ & No & 9 \\
\hline 5 & M & 70 & Neoplasia & $\begin{array}{l}\text { Odontoid pathological } \\
\text { fracture }\end{array}$ & $\begin{array}{l}\text { C1 lateral mass screws, } \\
\text { C2 pedicle and lateral } \\
\text { mass in C3- } 4\end{array}$ & No & 6 \\
\hline 6 & $\mathrm{~F}$ & 37 & Trauma & Transverse ligament injury & $\begin{array}{l}\text { C1 lateral mass screws } \\
\text { and C2 laminar screws }\end{array}$ & No & 16 \\
\hline 7 & F & 41 & Neoplasia & $\begin{array}{l}\text { Instability after } \mathrm{C} 3-4-5 \\
\text { corpectomy to treat a giant } \\
\text { cell tumor and posterior } \\
\text { spinal cord compression* }\end{array}$ & $\begin{array}{l}\text { Occipital screws, C2 } \\
\text { pars screws, lateral } \\
\text { mass C5-7-T1-2 }\end{array}$ & $\begin{array}{l}\text { Superficial } \\
\text { surgical wound } \\
\text { infection }\end{array}$ & 24 \\
\hline 8 & M & 60 & Congenital & Basilar invagination* & $\begin{array}{c}\text { Occipital fixation with } \\
\text { wiring and C2 pars } \\
\text { screws and C3 lateral } \\
\text { mass }\end{array}$ & $\begin{array}{l}\text { Superficial } \\
\text { surgical wound } \\
\text { infection }\end{array}$ & 17 \\
\hline 9 & $\mathrm{~F}$ & 12 & Congenital & Os odontoideum* & $\begin{array}{l}\text { Occipital fixation with } \\
\text { screws and C2 laminar } \\
\text { screws }\end{array}$ & No & 6 \\
\hline 10 & M & 36 & Trauma & $\begin{array}{l}\text { C2 fracture and C1-2 } \\
\text { subluxation }\end{array}$ & $\begin{array}{l}\text { Lateral mass screws } \\
\text { at C1, C2 pars and C3 } \\
\text { lateral mass }\end{array}$ & No & 2 \\
\hline 11 & M & 71 & Degenerative & $\begin{array}{l}\text { Revision surgery for anterior } \\
\text { C2-3-4 fixation* }\end{array}$ & $\begin{array}{l}\text { C2 pars screws, and } \\
\text { C3-4 lateral mass }\end{array}$ & No & 10 \\
\hline 12 & M & 20 & Trauma & $\begin{array}{c}\text { Lateral mass } \mathrm{C} 1 \text { fracture and } \\
\text { TL injury }\end{array}$ & Occipito-C2 pars-C3 & No & 6 \\
\hline 13 & M & 24 & Trauma & Odontoid fracture & C1-C2 laminar screws & No & - \\
\hline 14 & $\mathrm{~F}$ & 73 & Degenerative & Cervical myelopathy & $\begin{array}{l}\text { C2 laminar } \\
\text { (bilateral)-C4-5-6 Right } \\
\text { and C6 (Left) }\end{array}$ & No & 10 \\
\hline 15 & M & 47 & Congenital & Basilar invagination & Occipito-C2 laminar-C3 & $\begin{array}{l}\text { Superficial } \\
\text { wound infection }\end{array}$ & 8 \\
\hline 16 & $\mathrm{~F}$ & 45 & $\begin{array}{l}\text { Post-laminectomy } \\
\text { kyphosis }\end{array}$ & Cervical schwannoma & $\begin{array}{l}\text { C2 pedicle and } \\
\text { pars-C3-4-5- } 6\end{array}$ & No & 6 \\
\hline 17 & $\mathrm{~F}$ & 31 & $\begin{array}{c}\text { Inflammatory } \\
\text { (Rheumatoid arthritis) }\end{array}$ & Ligament transverse injury & $\begin{array}{l}\text { C1 lateral mass with C2 } \\
\text { laminar unilateral left } \\
\text { side }\end{array}$ & No & 4 \\
\hline
\end{tabular}

Patient 7 - had an arthrodesis review due to breaking of one occipital rod. We took it out, maintained the C2 fixation as the only point of cranial fixation. The patient had a very good clinical improvement, restarting ambulation after surgery, without the severe preoperative pain, even after removing the occipital plate. Patient 14 - the proposal surgery was a C3-6 decompression without included C2. During the surgical procedure, due to a severe osteoporotic bone, we had problems with the left C3-4-5 lateral masses. Once we did not have an adequate study of the C2 anatomy and we need a more cranial fixation point, we used C2 laminar screws.

Patient 15 - we had a strong difficult in contour the occipital rod with the direction of the C2 laminar screws and the C3 lateral mass screws. Based on this case, we did not use laminar screws in the middle of any construction since that.

Patient 17 - the right C1 lateral mass was destroyed. We performed an unilateral C1-2 fixation with autologous bone graft. The patient improved completely from her cervical neck pain (four months follow-up).

Since many anatomical variations can be found in the axis, it is necessary that the surgeon knows how to perform all the different techniques of fixation. As a general rule, in patients with an adequate pedicle size (greater than $4 \mathrm{~mm}$ and without a medially located vertebral artery), one can choose the pedicle screw fixation, with the screw reaching the axis body ${ }^{19}$. The use of pars screws, although also associated with some risk of vertebral artery injury ${ }^{19}$, can be safely used in almost all cases as long as the posterior margin of the vertebral body, viewed with the intraoperative lateral fluoroscopy, is not reached. Regarding the fact that the transverse foramen, where the vertebral artery can be injured, is positioned lateral to the axis body, we have used 16 millimeter screws in the pars, regardless of the medial or lateral 

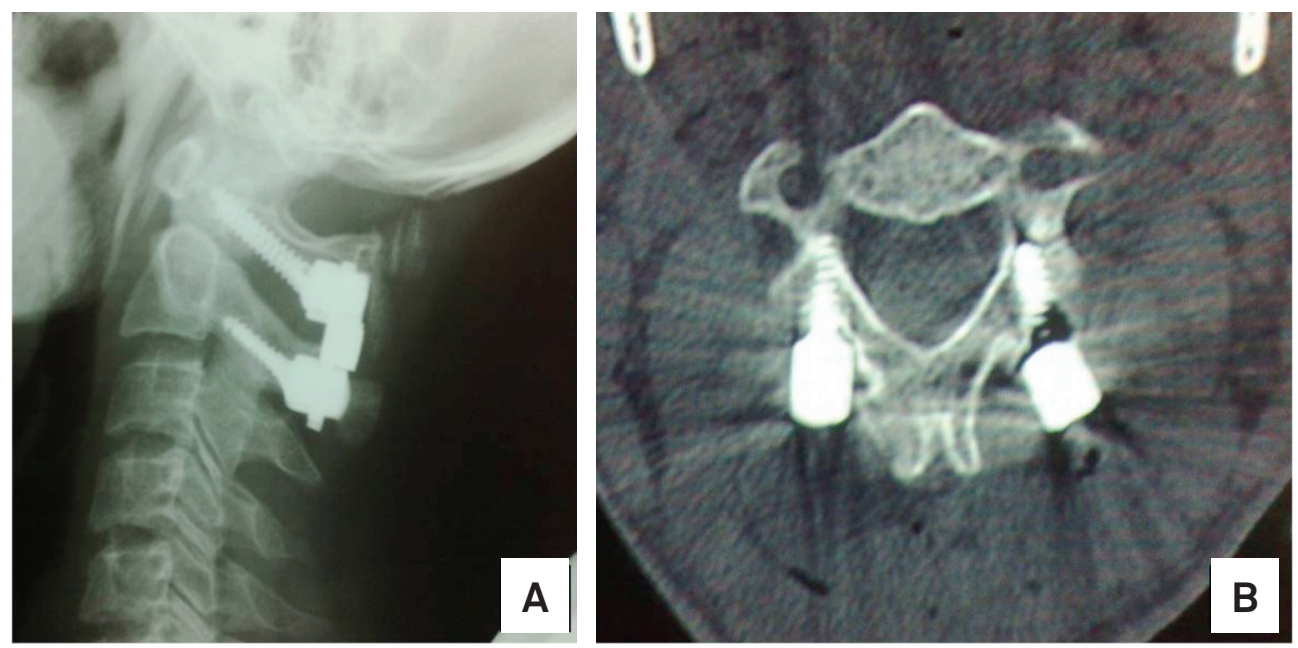

Fig 1. A C1-C2 fusion for treatment of an odontoid type II fracture. Bilateral C2 pars screws were used, with C1 lateral mass screws.
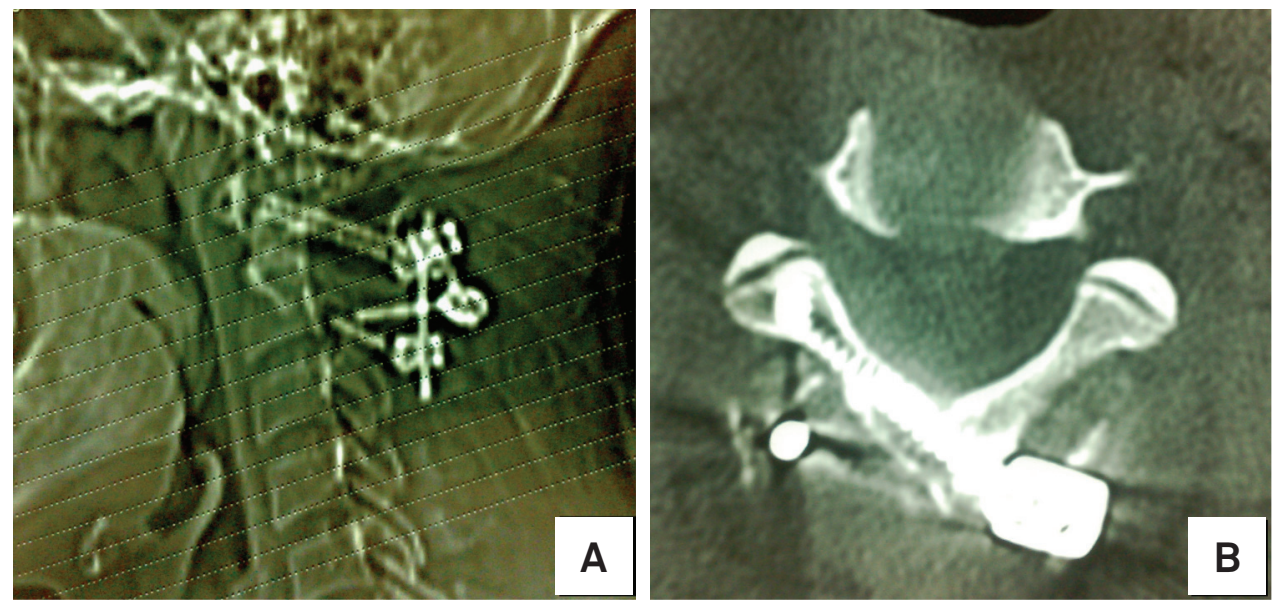

Fig 2. A C1-C2 fusion for treatment of a traumatic injury in substance of the transverse ligament, with C1-C2 instability. A hybrid construction was used with laminar and pars screws. (A) Sagittal CT scan reconstruction and (B) axial CT scan showing a right C2 pars screws and a left C2 laminar screw.
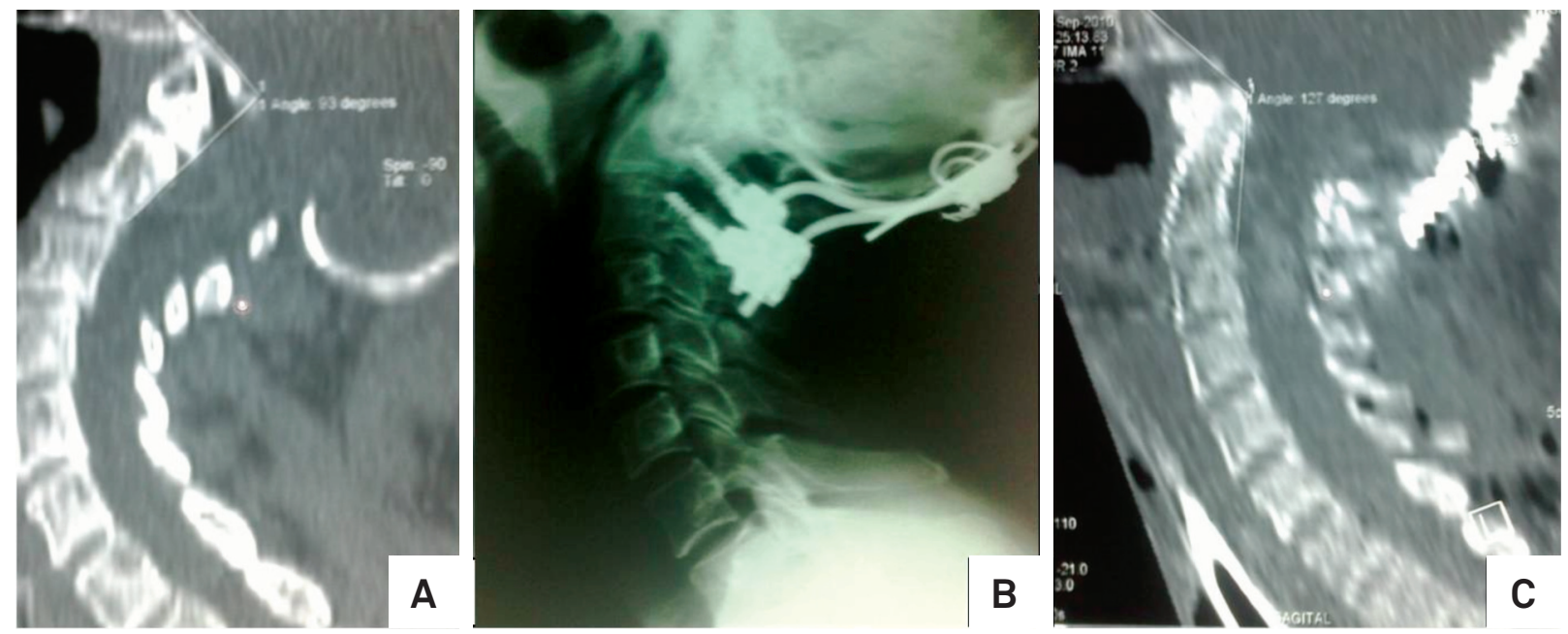

Fig 3. An occipitocervical fusion after traction for treatment of a basilar impression. Bilateral C2 pars screws were used, with Wackenheim clivus baseline changed from $93^{\circ}$ preoperatively (A) for $127^{\circ}$ at the post operatory (B and C). The patient improved of all his neurological symptoms with a solid fixation. 


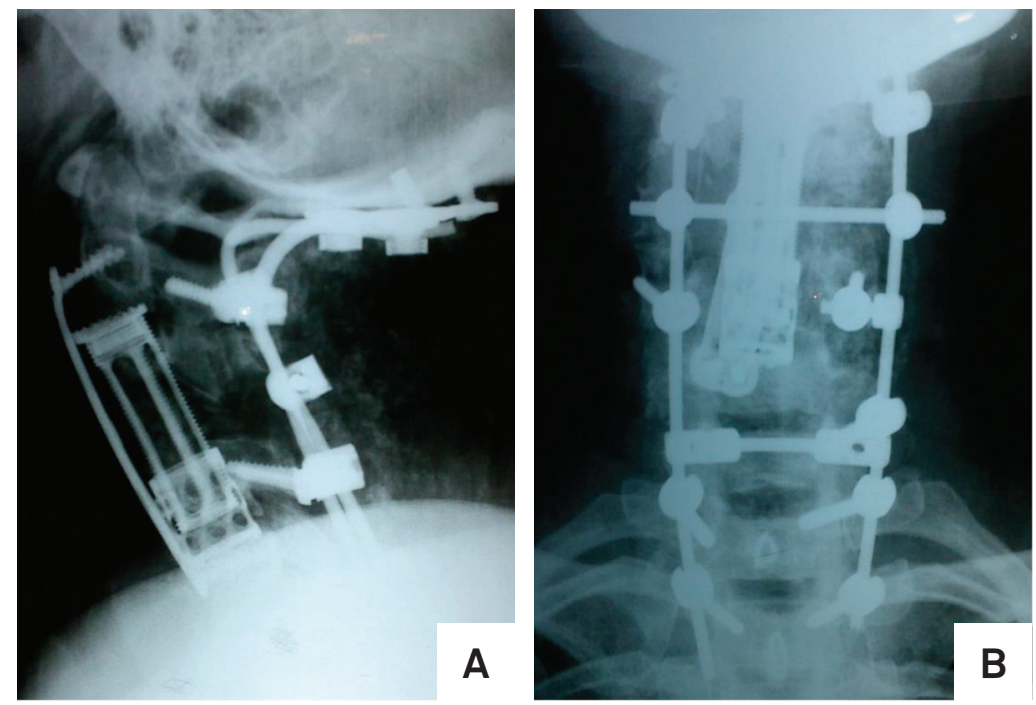

Fig 4. A complex occipitocervico-thoracic fusion for treatment of a giant cell tumor surgically treated previously by an anterior approach (three level corpectomy). Note that we used bilateral C2 pars screws.
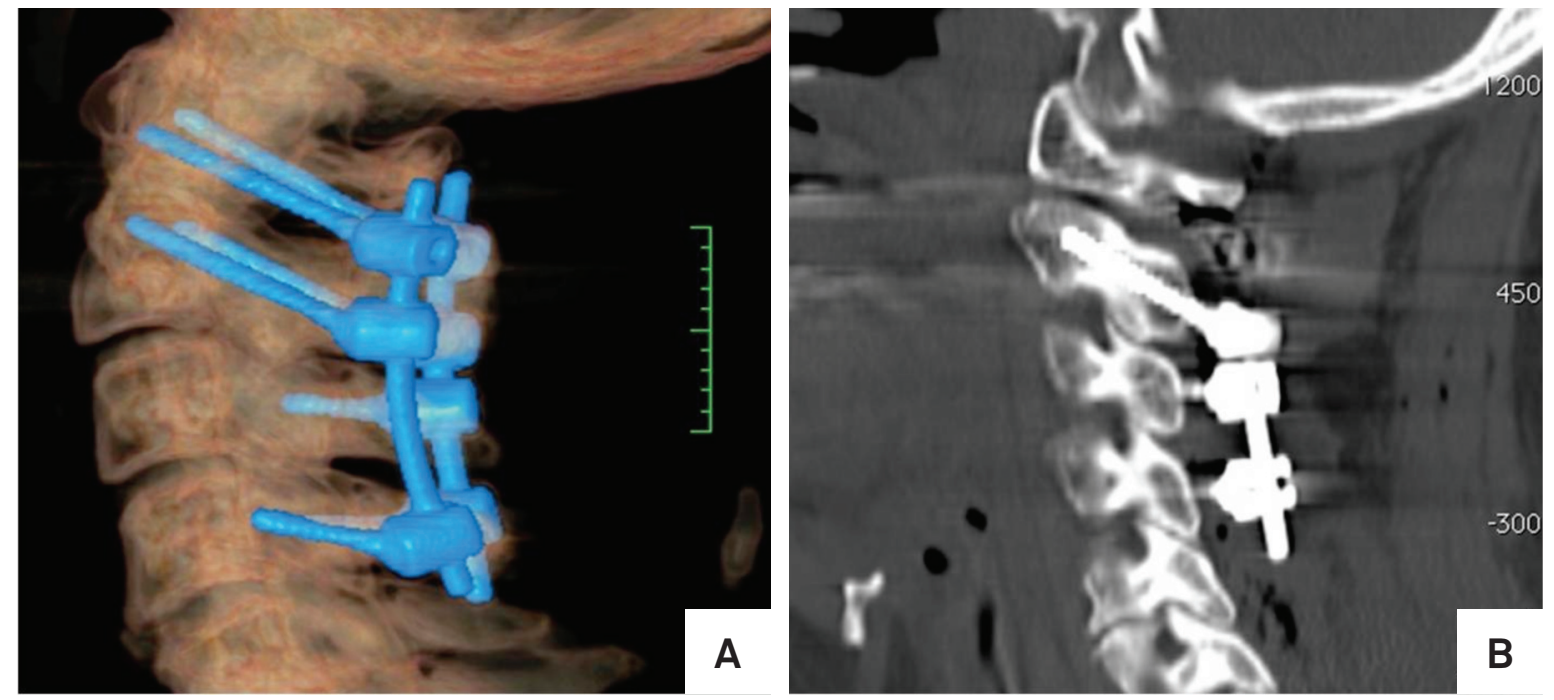

Fig 5. A C1-C4 stabilization for treatment of an odontoid pathological fracture. We use long bilateral C2 pedicular screws.

position of the vertebral artery, just making sure we did not trespass the posterior limit of the axis body. This is the reason for the large number of pars screws used in this series (13 out of 22 screws). Corroborating our results, Hoh et al., after evaluation of $50 \mathrm{CT}$ scan reconstructions of adult individuals, reported that $14 \mathrm{~mm}$ pars screws could be used in almost $99 \%$ of the cases, if the correct trajectory of insertion was respected ${ }^{19}$.

Concerning the efficacy of the techniques, in a biomechanical cadaveric study of 11 fresh frozen specimens, insertional torque and pull-out strength were measured in initial and salvage procedures. The authors suggested that pedicle screws provide the strongest fixation for both initial and salvage applications $(\mathrm{p}<0.0001)$. If they should fail, lamina screws appear to provide stronger and more reproducible fixation than pars screws ${ }^{20}$.
Table 2. Distribution of the 11 patients with axis instrumentation according to the surgical technique used.

\begin{tabular}{llc} 
Technique & $\mathrm{n}$ & Percentage \\
\hline Pars & 7 & 41.1 \\
Lamina & 5 & 29.4 \\
Pedicle & 2 & 16.6 \\
Lamina and pars & 1 & 5.8 \\
Pedicle and pars & 1 & 5.8 \\
Lamina (unilateral) & 1 & 5.8 \\
\hline
\end{tabular}

In a retrospective clinical study of Parker et al., they revised 167 patients (313 screws) that underwent a posterior cervical arthrodesis with $\mathrm{C} 2$ pedicular screws or, when anatomically precluded, had laminar screws placed ${ }^{21}$. The authors divided the groups in axial (C1-2 or C1-2-3) and subaxial. They reported that, in both groups, 11 (7\%) of the pedicle 
screws breached the pedicle (none of them required acute revision) versus only 2 (1.3\%) of the laminar screws (one of them required acute revision) $(\mathrm{p}=0.018)$. A higher incidence of pseudoarthrosis in the laminar group was reported, requiring reoperation in 4 patients $(6.1 \%)$ versus no patient reoperated in the pedicle group $(\mathrm{p}<0.05)$, but just in subaxial constructions, after one year postoperative. No case of axial fusion in both groups required surgery review for pseudoarthrosis. They concluded that both techniques were very effective and safe in both axial (C1-2 and C1-2-3) and subaxial constructions, with a small durability for translaminar fusion in the subaxial spine.

In one of our cases, an occipit-C2-3 fixation was performed (patient 15). In this case, we chose to use laminar screws in $\mathrm{C} 2$. We have an important difficult in rod contouring, even using poliaxial screws, once the screws directions were completely different. Based on this case, we do not recommend using C2 laminar screws when this level is not the most caudal or rostral of the construction.

When large fixation is required, as in cervicothoracic fixation stopping at $\mathrm{C} 2$, we tried to use pedicle screws because they have the stronger purchase. However, we emphasized that the use of $\mathrm{C} 2$ pedicle screws is the most demanding and risky technique, justifying our small rate of its utilization in this series.

Although we do not use this technique for axis fixation in any case in this series because of surgeon's personal preference (AFJ) in using $\mathrm{C} 1$ lateral mass screws, C1-2 transarticular screw fixation to stabilize $\mathrm{C} 1$ and $\mathrm{C} 2$ is widely used and described in literature ${ }^{22}$. Even though technically more challenged, requiring a CT angiogram study before its use to visualize the vertebral artery course in the C1-2 region, biomechanical studies suggest that this construction provides the highest level of stability in this region ${ }^{22}$.
Based on our literature review and learnt experience, we suggest the algorithm presented in Fig 6 to choose the best technique for axis fixation. It's important to mention that, even though pars screws was the most common technique used in this series, after a learning curve period, we try to use pedicle screws in selected patients with good anatomical profile when a more strong fixation is needed.

In conclusion, axis instrumentation was safe and efficient in our series, regardless of the technique used for stabilization. The choice of the technique must be based on the anatomical peculiarities of each patient and on surgeon's preference. Whenever it's possible, pedicle screws provide the stronger fixation. In this series, the use of pars screws was also safe and efficient. Laminar screws can be an option, considering its use when the fixation stops at the level of the axis.

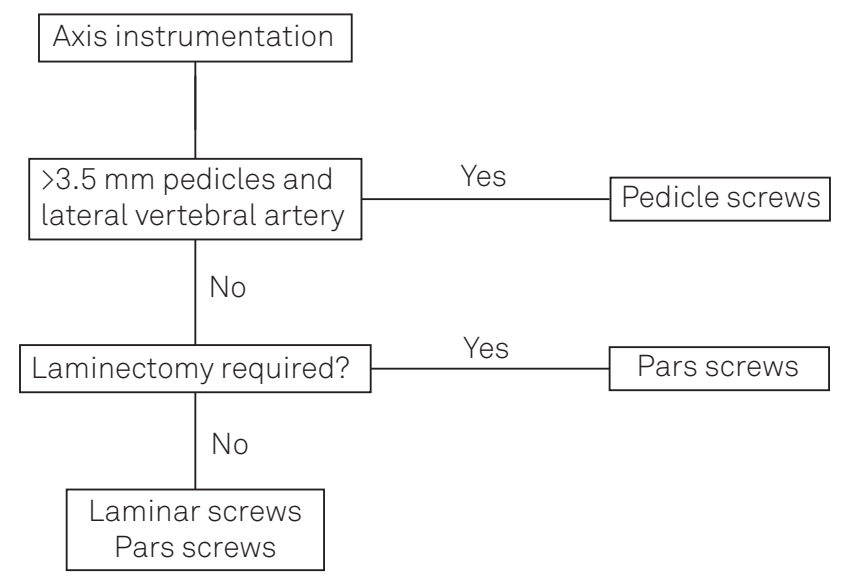

Fig 6. Algorithm proposed for chosen the best axis screw instrumentation technique.

\section{References}

1. Joaquim AF, Patel AP. Occipito cervical trauma: evaluation, classification and treatment. Contemp Spine Surg 2010;11:1-5.

2. Joaquim AF, Patel AP. C1 and C2 spine trauma: evaluation, classification and treatment. Contemp Spine Surg 2010;11:1-7.

3. Joaquim AF, Patel AP. Occipito cervical trauma: evaluation, classification and treatment. Contemp Neurosurg 2010;32:1-6.

4. Joaquim AF, Ghizoni E, Rubino PA, et al. Lateral mass screws fixation of the atlas: surgical technique and anatomy. World Neurosurg 2010;74:395-399.

5. Mudo ML, Amantéa AV, Cavalheiro S, Joaquim AF. Intraoperative radiological visualization of the occipito-cervical transition and upper cervical spine: technical note. Coluna/Columna 2009;8:197-199.

6. Farey ID, Nadkarni S, Smith N. Modified Gallie technique versus transarticular screw fixation in C1-C2 fusion. Clin Orthop Relat Res 1999;359:126-135.

7. Dickman CA, Sonntag VK. Posterior C1-C2 transarticular screw fixation for atlantoaxial arthrodesis. Neurosurgery 1998;43:275-280.

8. Coyne TJ, Fehlings MG, Wallace MC, Bernstein M, Tator CH. C1-C2 posterior cervical fusion: long-term evaluation of results and efficacy. Neurosurgery 1995;37:688-692.
9. Crisco JJ 3rd, Panjabi MM, Oda T, Grob D, Dvorak J. Bone graft translation of four upper cervical spine fixation techniques in a cadaveric model. J Orthop Res 1991;9:835-846.

10. Grob D, Crisco JJ 3rd, Panjabi MM, Wang P, Dvorak J. Biomechanical evaluation of four different posterior atlantoaxial fixation techniques. Spine 1992;17:480-490.

11. Henriques T, Cunningham BW, Olerud C, et al. Biomechanical comparison of five different atlantoaxial posterior fixation techniques. Spine 2000;25:2877-2883.

12. Melcher RP, Puttlitz CM, KleinstueckFS, LotzJC, Harms J, Bradford DS Biomechanical testing of posterior atlantoaxial fixation techniques. Spine 2002;27:2435-2440.

13. Goel A, Laheri V. Plate and screw fixation for atlanto-axial subluxation. Acta Neurochir (Wien) 1994;129:47-53.

14. Mandel IM, Kambach BJ, Petersilge CA, Johnstone B, Yoo JU. Morphologic considerations of $\mathrm{C} 2$ isthmus dimensions for the placement of transarticular screws. Spine 2000;25:1542-1547.

15. Igarashi T, Kikuchi S, Sato K, Kayama S, Otani K. Anatomic study of the axis for surgical planning of transarticular screw fixation. Clin Orthop Relat Res 2003;408:162-166. 
16. Yanni DS, Perin NI. Fixation of the axis. Neurosurgery. 2010;66:147-152.

17. Wright NM. Posterior C2 fixation using bilateral, crossing C2 laminar screws: case series and technical note. J Spinal Disord Tech 2004;17:158-162.

18. Ebraheim NA, Fow J, Xu R, Yeasting RA. The location of the pedicle and pars interarticularis in the axis. Spine 2001;26:E34-37.

10. Hoh DJ, Liu CY, Wang MY. A radiographic computed tomographybased study to determine the ideal entry point, trajectory, and length for safe fixation using C-2 pars interarticularis screws. J Neurosurg Spine 2010;12:602-612.
20. Lehman RA, Dmitriev AE, Helgeson MD, Sasso RC, Kuklo TR, Riew KD. Salvage of C2 pedicle and pars screws using the intralaminar technique: a biomechanical analysis. Spine 2008;33:960-965

21. Parker SL, McGirt MJ, Garcés-Ambrossi GL, et al. Translaminar versus pedicle screw fixation of $\mathrm{C} 2$ : comparison of surgical morbidity and accuracy of 313 consecutive screws. Neurosurgery. 2009;64: 343-348.

22. Sim HB, Lee JW, Park JT, Mindea SA, Lim J, Park J. Biomechanical evaluations of various c1-c2 posterior fixation techniques. Spine 2011:36:E401-407. 